\title{
BOOKS RECEIVED/LIVRES REÇUS
}

Abraham, Sara, Labour and the Multiracial Project in the Caribbean. Lanham MD: Rowman \& Littlefield, 2007, 258 pp., \$US 32.95 paper (978-07391-1686-9), \$US 75.00 hardcover (978-0-7391-1685-2).

Adam, Barbara, Future Matters: Action, Knowledge, Ethics. Supplements to the Study of Time, 3. Leiden: BRILL, 2007, 218 pp., \$US 84.00 hardcover (978-9-0041-6177-1).

Adorno, Theodor W., Letters to His Parents: 1939-1951. Oxford: Polity Press, 2007, 397 pp., \$53.99 hardcover (978-0-7456-3542-2).

Adorno, Theodor W., Dream Notes. Oxford: Polity Press, 2007, 128 pp., \$21.99 hardcover (978-0-7456-3830-0).

Andersen, Robert, Modern Methods for Robust Regression. Quantitative Applications in the Social Sciences. London and Los Angeles: Sage, 2007, 128 pp., \$US 16.95 paper (978-1-4129-4072-6).

Archer, Margaret S., Making our Way through the World: Human Reflexivity and Social Mobility. New York: Cambridge University Press, 2007, 352 pp., \$US 34.99 paper (978-0-5216-9693-7), \$US 90.00 hardcover (9780-5218-7423-6).

Asada, Yukiko, Health Inequality: Morality and Measurement. Toronto: University of Toronto Press, 2007, 256 pp., \$55.00 hardcover (0802092446).

Augoyard, Jean-François, Step by Step: Everyday Walks in a French Urban Housing Project. Translated and with an afterword by David Ames Curtis. Foreword by Françoise Choay. Minneapolis: University of Minnesota Press, 2007, 280 pp., \$US 22.50 paper (978-0-8166-4591-6), \$US 67.50 hardcover (978-0-8166-4590-9).

Badiou, Alain, The Century. Oxford: Polity Press, 2007, 248 pp., \$27.99 paper (978-0-7456-3632-0), \$77.99 hardcover (978-0-7456-3631-3).

Baudrillard, Jean, Cool Memories V: 2000-2004. Translated by Chris Turner. Oxford: Polity Press, 2006, 114 pp., \$23.99 paper (978-0-7456-3660-3), \$67.99 hardcover (978-0-7456-3659-7).

Bauman, Zygmunt, Liquid Fear. Oxford: Polity Press, 2006, 200 pp., \$22.99 paper (978-0-7456-3680-1), \$68.99 hardcover (978-0-7456-3679-5).

Bauman, Zygmunt, Liquid Times: Living in an Age of Uncertainty. Oxford: Polity Press, 2007, 115 pp., \$17.99 paper (978-0-7456-3987-1).

Baumann, Shyon, Hollywood Highbrow: From Entertainment to Art. Princeton Studies in Cultural Sociology. Princeton: Princeton University Press, 2007, 242 pp., \$US 35.00 hardcover (978-0-6911-2527-5).

Becker, Howard S., Telling About Society. Chicago Guides to Writing, Editing, and Publishing. Chicago: University of Chicago Press, 2007, 304 
pp., \$US 15.00 paper (978-0-2260-4126-1), \$US 37.50 hardcover (9780-2260-4125-4).

Becker, Howard S., Writing for Social Scientists: How to Start and Finish Your Thesis, Book, or Article, Second Edition. Contribution by Pamela Richards. Chicago Guides to Writing, Editing, and Publishing. Chicago: University of Chicago Press, 2007, 208 pp., \$US 12.00 paper (978-0-22604132-2), \$US 30.00 hardcover (978-0-2260-4130-8).

Beyer, Peter and Lori Beaman, eds., Religion, Globalization, and Culture. International Studies in Religion and Society, 6. Leiden: BRILL, 2007, 608 pp., \$US 99.00 paper (978-9-0041-5407-0).

Blaikie, Norman, Approaches to Social Enquiry: Advancing Knowledge. Oxford: Polity Press, 2007, 288 pp., \$32.99 paper (978-0-7456-3449-4), \$83.99 hardcover (978-0-7456-3448-7).

Boyd, Susan C., Hooked: Drug War Films in Britain, Canada, and the U.S. New York: Routledge, 2007, 262 pp., \$US 95.00 hardcover (978-0-41595706-9)

Bradley, Harriet, Gender. Key Concepts. Oxford: Polity Press, 2007, 240 pp., \$29.99 paper (978-0-7456-2377-1), \$77.99 hardcover (978-0-74562376-4).

Callinicos, Alex, Social Theory: A Historical Introduction, 2nd Edition. Oxford: Polity Press, 2007, 368 pp. \$35.99 paper (978-0-7456-3840-9).

Candelario, Ginetta E.B., Black Behind the Ears: Dominican Racial Identity from Museums to Beauty Shops. Durham, NC: Duke University Press, 2007, 360 pp., \$US 23.95 paper (978-0-8223-4037-9), \$US 84.95 hardcover (978-0-8223-4018-8).

Chriss, James, Social Control. Oxford: Polity Press, 2007, 240 pp., \$30.99 paper (978-0-7456-3858-4), \$77.99 hardcover (978-0-7456-3857-7).

Çinar, Alev and Thomas Bender, eds., Urban Imaginaries: Locating the Modern City. Minneapolis: University of Minnesota Press, 2007, 336 pp., \$US 25.00 paper (978-0-8166-4802-3), \$US 75.00 hardcover (978-08166-4801-6).

Close, Carl P. and Robert Higg, eds., Opposing the Crusader State: Alternatives to Global Interventionism. Oakland, CA and Washington, DC: The Independent Institute, 2007, 320 pp., \$US 15.95 paper (978-1-59813015-7).

Desmond, Matthew, On the Fireline: Living and Dying with Wildland Firefighters. Fieldwork Encounters and Discoveries. Chicago: University of Chicago Press, 2007, 368 pp., \$US 24.00 hardcover (978-0-2261-4408-5).

Ericson, Richard, Crime in an Insecure World. Oxford: Polity Press, 2006, 256 pp., \$23.99 paper (978-0-7456-3829-4), \$65.99 hardcover (978-0-74563828-7).

Fallis, George, Multiversities, Ideas, and Democracy. Toronto: University of Toronto Press, 2007, 424 pp., \$65.00 hardcover (0802092403). 
Feng, Wang, Boundaries and Categories: Rising Inequality in Post-Socialist Urban China. Studies in Social Inequality. Stanford: Stanford University Press, 2007, 264 pp., \$US 55.00 hardcover (978-0-8047-5794-2).

Frauley, Jon and Frank Pearce, eds., Critical Realism and the Social Sciences: Heterodox Elaborations. Toronto: University of Toronto Press, 2007, 336 pp., \$65.00 hardcover (0802092152).

Grazian, David, On the Make: The Hustle of Urban Nightlife. Chicago: University of Chicago Press, 2007, 256 pp., \$US 25.00 hardcover (978-02263-0567-7).

Hervouet, Ronan, Datcha Blues: Existences ordinaires et dictatures en Bilorussie. Mondes contemporains. Montreuil, France: Aux Lieux d'Etre, 2007, 193 pp., 17.00€ paper (978-2-9160-6349-2).

Holland, Stephen, Public Health Ethics. Oxford: Polity Press, 2007, 240 pp., \$29.99 paper (978-0-7456-3303-9), \$88.74 hardcover (978-0-74563302-2).

Honneth, Axel, Disrespect: The Normative Foundations of Critical Theory. Oxford: Polity Press, 2007, 296 pp., \$31.99 paper (978-0-7456-2906-3), \$71.99 hardcover (978-0-7456-2905-6).

Howarth, Glennys, Death and Dying: A Sociological Introduction. Oxford: Polity Press, 2007, 312 pp., \$29.99 paper (978-0-7456-2534-8), \$71.99 hardcover (978-0-7456-2533-1).

Hunt, Gerald and David Rayside, eds. Equity, Diversity, and Canadian Labour. Toronto: University of Toronto Press, 2007, 304 pp., \$29.95 paper (0802086349), \$70.00 hardcover (0802089569).

Illouz, Eva, Cold Intimacies: The Making of Emotional Capitalism. Oxford: Polity Press, 2006, 144 pp., \$23.99 paper (978-0-7456-3905-5), \$71.99 hardcover (978-0-7456-3904-8).

Johnson, Gerry, Strategy as Practice: Research Directions and Resources. New York: Cambridge University Press, 2007, 258 pp., \$US 39.99 paper (9780-5216-8156-8), \$US 110.00 hardcover (978-0-5218-6293-6).

Jones, Esyllt W., Influenza 1918: Disease, Death, and Struggle in Winnipeg. Studies in Gender and History. Toronto: University of Toronto Press, 2007, 240 pp., \$27.95 paper (0802094392), \$65.00 hardcover (0802091970).

Ladi, Zaki, The Great Disruption. Oxford: Polity Press, 2007, 272 pp., \$29.99 paper (978-0-7456-3664-1), \$77.99 hardcover (978-0-7456-3663-4).

Lawrence, Bruce B. and Aisha Karim, eds. On Violence: A Reader. Durham, NC: Duke University Press, 2007, 592 pp., \$US 29.95 paper (978-08223-3769-0), \$US 99.95 hardcover (978-0-8223-3756-0).

Lehmann, Wolfgang, Choosing to Labour? School-Work Transitions and Social Class. Montreal and Kingston: McGill-Queen's University Press, 2007, 232 pp., \$27.95 paper (978-0-7735-3306-6), \$75.00 hardcover (978-07735-3280-9). 
Liberman, Kenneth B., Husserl's Criticism of Reason: With Ethnomethodological Specifications. Lanham, MD: Lexington Books, 2007, 212 pp., \$US 65.00 hardcover (978-0-7391-1118-5).

Lloyd, Moya, Judith Butler: From Norms to Politics. Key Contemporary Thinkers. Oxford: Polity Press, 2007, 216 pp., paper (978-0-7456-2377-1), hardcover (978-0-7456-2376-4).

Marwell, Nicole P., Bargaining for Brooklyn: Community Organizations in the Entrepreneurial City. Chicago: University of Chicago Press, 2007, 288 pp., \$US 22.00 paper (978-0-2265-0907-5), \$US 55.00 hardcover (9780-2265-0906-8).

McLean, Paul D., The Art of the Network: Strategic Interaction and Patronage in Renaissance Florence. Politics, History and Culture. Durham, NC: Duke University Press, 2007, 304 pp., \$US 22.95 paper (978-0-82234117-8), \$US 79.95 hardcover (978-0-8223-4100-0).

Milton, Cynthia E., The Many Meanings of Poverty: Colonialism, Social Compacts, and Assistance in Eighteenth-Century Ecuador. Stanford: Stanford University Press, 2007, 384 pp., \$US 65.00 hardcover (978-0-80475178-0).

Mische, Ann, Partisan Publics: Communication and Contention across Brazilian Youth Activist Networks. Princeton Studies in Cultural Sociology. Princeton: Princeton University Press, 2007, 458 pp., \$US 39.50 hardcover (978-0-6911-2494-0).

Modood, Tariq, Multiculturalism. Oxford: Polity Press, 2007, 160 pp., $\$ 23.99$ paper (978-0-7456-3289-6).

Moore, Dawn, Criminal Artefacts: Governing Drugs and Users. Law and Society. Vancouver: University Of British Columbia Press, 2007, 208 pp., \$85.00 hardcover (978-0-7748-1386-0).

Morton, Stephen, Gayatri Spivak: Ethics, Subalternity and the Critique of Postcolonial Reason. Key Contemporary Thinkers. Oxford: Polity Press, 2007, 216 pp., \$27.99 paper (978-0-7456-3285-8), \$71.99 hardcover (978-0-7456-3284-1).

Nelsen, Randle W., Fun \& Games \& Higher Education: The Lonely Crowd Revisited. Toronto: Between the Lines, 2007, 140 pp., \$24.95 paper (9781-897071-31-1).

Orsini, Michael, Critical Policy Studies. Vancouver: University Of British Columbia Press, 2006, 400 pp., \$29.95 paper (978-0-7748-1317-4), \$85.00 hardcover (978-0-7748-1317-4).

Payne, Sarah, The Health of Men and Women. Oxford: Polity Press, 2006, 240 pp., \$29.99 paper (978-0-7456-3454-8), \$75.99 hardcover (978-0-74563453-1).

Pierson, Chris and Francis Castles, eds., The Welfare State Reader, 2nd Edition. Oxford: Polity Press, 2007, 404 pp., \$39.99 paper (978-0-7456-3556-9), \$86.99 hardcover (978-0-7456-3555-2). 
Pitts, Marian and Anthony Smith, eds., Researching the Margins: Strategies for Ethical and Rigorous Research With Marginalised Communities. New York: Palgrave Macmillan, 2007, 256 pp., \$US 74.95 hardcover (1-4039-1811-2).

Powell, Benjamin, Making Poor Nations Rich: Entrepreneurship and the Process of Economic Development. Stanford: Stanford University Press/Independent Institute, 2007, 480 pp., \$US 29.95 paper (978-0-8047-57324), \$US 75.00 hardcover (978-0-8047-5731-7).

Razack, Sherene H., Casting Out: The Eviction of Muslims from Western Law and Politics. Toronto: University of Toronto Press, 2008, 240 pp., \$24.95 paper (080209497X), \$60.00 hardcover (0802093116).

Reed, Isaac and Jeffrey C. Alexander, eds., Culture, Society, and Democracy. Boulder: Paradigm Publishers, 2007, 208 pp., \$US 27.95 paper (978-15945-1342-8), \$US 79.00 hardcover (978-1-5945-1341-1).

Riessman, Catherine Kohler, Narrative Methods for the Human Sciences. Qualitative Research Methods. London and Los Angeles: Sage, 2007, 264 pp., \$US 34.95 paper (978-0-7619-2998-7), \$US hardcover (9780-7619-2997-0).

Rodden, John, ed., The Cambridge Companion to George Orwell. Cambridge Companions to Literature. New York: Cambridge University Press, 2007, 238 pp., \$US 24.99 paper (978-0-5216-7507-9), \$US 80.00 hardcover (978-0-5218-5842-7).

Sako, Teruhito, ed., Japanese Family and Society: Words from Tongo Takebe, A Meiji Era Sociologist. Binghamton, NY: Haworth Press, 2007, 260 pp., \$US 39.95 paper (978-0-7890-3261-4), \$US 59.95 hardcover (978-07890-3260-7).

Sales, Arnaud and Marcel Fournier, eds., Knowledge, Communication and Creativity. SAGE Studies in International Sociology. Thousand Oaks, CA: Sage, 2007, 208 pp., \$US 99.00 hardcover (978-0-7619-4306-8).

See, Letha A., Human Behavior in the Social Environment from an AfricanAmerican Perspective, Second Edition. Binghamton, NY: Haworth Press, 2007, 782 pp., \$US 69.95 paper (978-0-7890-2832-7), \$US 89.95 hardcover (978-0-7890-2831-0).

Smelser, Neil J., The Faces of Terrorism: Social and Psychological Dimensions. Princeton: Princeton University Press, 2007, 292 pp., \$US 29.95 hardcover (978-0-6911-3308-9).

Smith, Miriam, ed., Group Politics and Social Movements in Canada. Peterborough: Broadview Press, 2007, 378 pp., \$32.95 paper (978-1-55111771-3).

Sorek, Tamir, Arab Soccer in a Jewish State: The Integrative Enclave. Cambridge Cultural Social Studies. New York: Cambridge University Press, 2007, 240 pp., \$US 91.00 hardcover (978-0-5218-7048-1).

St. Jean, Peter K.B. Pockets of Crime: Broken Windows, Collective Efficacy, and the Criminal Point of View. Chicago: University of Chicago Press, 
2007, 256 pp., \$US 23.00 paper (978-0-2267-7499-2), \$US 59.00 hardcover (978-0-2267-7498-5).

Staggenborg, Suzanne, Social Movements. Don Mills: Oxford University Press, 2007, 173 pp., \$39.95 paper (78-0-1954-2309-9).

Steinmetz, George, The Devil's Handwriting: Precoloniality and the German Colonial State in Qingdao, Samoa, and Southwest Africa. Chicago Studies in Practices of Meaning. Chicago: University of Chicago Press, 2007, 608 pp., \$US 33.00 paper (978-0-2267-7243-1), \$US 90.00 hardcover (978-0-2267-7241-7).

Sutton, Philip W., The Environment: A Sociological Introduction. Oxford: Polity Press, 2007, 208 pp., \$31.99 paper (978-0-7456-3433-3), \$75.99 hardcover (978-0-7456-3432-6).

Szasz, Andrew, Shopping Our Way to Safety: How We Changed from Protecting the Environment to Protecting Ourselves. Minneapolis: University of Minnesota Press, 2007, 320 pp., \$US 24.95 hardcover (978-0-81663508-5).

Taylor, Charles, A Secular Age. Cambridge, MA: Harvard University Press, 2007, 896 pp.,\$US 39.95 hardcover (978-0-6740-2676-6).

Vale, Lawrence J., From the Puritans to the Projects: Public Housing and Public Neighbors. Cambridge, MA: Harvard University Press, 2007, 482 pp., \$US 22.50 paper (978-0-6740-2575-2), \$US 59.50 hardcover (9780-6740-0286-9).

Virilio, Paul, The Original Accident. Oxford: Polity Press, 2006, 128 pp., \$23.99 paper (978-0-7456-3614-6), \$65.99 hardcover (978-0-7456-3613-9).

Weiner, Elaine, Market Dreams: Gender, Class, and Capitalism in the Czech Republic. Ann Arbor: University of Michigan Press, 2007, 168 pp., \$US 22.95 paper (978-0-4720-6988-0), \$US 60.00 hardcover (978-0-47209988-7).

Whimster, Sam, Understanding Weber. New York: Routledge, 2007, 312 pp., \$US 41.95 paper (978-0-4153-7076-9), \$US 145.00 hardcover (978-04153-7075-2).

Wiseman, Nelson, In Search of Canadian Political Culture. Vancouver: University of British Columbia Press, 2007, 348 pp., \$29.95 paper (978-0-77481389-1), \$85.00 hardcover (978-0-7748-1388-4).

Wright, Stuart A., Patriots, Politics, and the Oklahoma City Bombing. Cambridge Studies in Contentious Politics. New York: Cambridge University Press, 2007, 254 pp., \$US 22.99 paper (9780521694193), \$US 70.00 hardcover (9780521872645).

Young, Margot, Susan B. Boyd, Gwen Brodsky, and Shelagh Day, eds., Poverty: Rights, Social Citizenship, and Legal Activism. Law and Society. Vancouver: University of British Columbia Press, 2007, 400 pp., \$29.95 paper (978-0-7748-1288-7), \$85.00 hardcover (978-0-7748-1287-0). 